\title{
裸 \\ MEMBENDUNG RADIKALISME DALAM DUNIA PENDIDIKAN MELALUI PENDEKATAN BRAIN BASED LEARNING
}

\author{
Zulfani Sesmiarni \\ IAIN Bukittinggi \\ zulfanisesmiarni@gmail.com
}

\begin{abstract}
Abstrak
Dunia pendidikan dewasa ini sering diwarnai oleh tindak kekerasan, tawuran antar sekolah, perkelahian antar pelajar sampai kepada pembunuhan antar pelajar. Ironisnya masalah tersebut terjadi pada lembaga pendidikan formal yang menjadi tempat pembentukan budaya dan karekter peserta didik. Artikel ini ini menawarkan suatu solusi untuk mencegah/menekan aksi kekerasan di kalangan pelajar melalui penggunaan metode pembelajaran brain-based teaching Metode ini menggabungkan 5 aspek pembelajaran yakni aspek emosional, sosial, kognitif, fisik dan reflektif. Pembentukan pribadi peserta didik dimulai dalam bentuk pembelajaran di kelas untuk mengembangkan kemampuan, potensi dan kompetensi peserta didik. Dengan cara ini peserta didik diharapkan terhindar dari berbagai kekerasan dan sikap apatis lainnya karena mereka telah dididik dalam suasana pembelajaran yang damai dan menyenangkan.
\end{abstract}

\begin{abstract}
The world of education today is often marred by violences, students fights, and crimes. Ironically, the problem occurs in formal educational institutions where the character building process is performed. This article offers a solution to prevent/suppress violence among students through the use of so-called the brain-based learning method. This method combines five aspects of learning i. e. emotional, social, cognitive, physical and reflective. The students personality formation process begins in the form of classroom learning to develop the abilities, potency and competence of learners. In this way the students are expected to escape from the violence and apathy of others as they have been accustomed to learn in a peaceful and pleasant environment.
\end{abstract}

Kata Kunci: Radikalisme, dunia pendidikan, brain based learning 


\section{A. Pendahuluan}

Pendidikan merupakan usaha sengaja untuk mendewasakan manusia muda menjadi manusia yang bertanggung jawab dan memiliki kemampuan tertentu sebagai penerus kebudayaan. Hal ini terdapat dalam Undang-Undang Sistem Pendidikan Nasional pasal 1 yang berbunyi "Pendidikan adalah usaha sadar dan terencana untuk mewujudkan suasana belajar dan proses pembelajaran agar peserta didik secara aktif mengembangkan potensi dirinya untuk memiliki kekuatan spiritual keagamaan, pengendalian diri, kepribadian, kecerdasan, akhlak mulia, serta keterampilan yang diperlukan dirinya, masyarakat, bangsa dan negara."1

Untuk mencapai tujuan pendidikan tersebut maka perlu ada komponen pendidikan yang saling berhubungan satu dengan yang lainnya. Di antaranya adalah Biaya, manajemen, tenaga pendidik, sarana prasarana, isi/kurikulum, proses dan evaluasi. Semua komponen ini saling berkaitan guna mencapai tujuan pendidikan yang diinginkan.

Selain itu Pendidikan nasional juga berfungsi mengembangkan kemampuan dan membentuk watak serta peradaban bangsa yang bermartabat dalam rangka mencerdaskan kehidupan bangsa, bertujuan untuk berkembangnya potensi peserta didik agar menjadi manusia yang beriman dan bertakwa kepada Tuhan Yang Maha Esa, berakhlak mulia, sehat, berilmu, cakap, kreatif, mandiri, dan menjadi warga negara yang demokratis serta bertanggung jawab (UUSPN. No.20 Thn 2003 pasal 3).

Hakikat pendidikan adalah proses memanusiakan anak manusia yaitu menyadari akan manusia yang merdeka. Manusia yang merdeka adalah manusia yang kreatif yang terwujud di dalam budayanya. Manusia dibesarkan di dalam habitatnya yang membudaya, dia hidup di dalam budayanya dan dia menciptakan atau mengkontruksi budayanya itu sendiri. Manusia berarti membudaya. ${ }^{2}$

Pendidikan idealnya merubah tingkah laku manusia dari hal-hal yang buruk menjadi lebih baik, bukan yang sebaliknya. Namun dari dahulu sampai sekarang selalu saja ada hal-hal negative

\footnotetext{
${ }^{1}$ UU No. 20 Tentang Sistem Pendidikan Nasional.

${ }^{2}$ Tilaar, Manifesto Pendidikan Nasional (Kompas: Jakarta, 2005), h. 112.
} 
dalam dunia pendidikan di Indonesia. Di antaranya adalah masalah radikalisme dalam dunia pendidikan.

Masalah radikalisme yang sering muncul akhir-akhir ini adalah masalah kekerasan, tawuran antar sekolah, perkelahian antar pelajar sampai kepada pembunuhan antar pelajar yang bermula dari hal-hal yang tidak serius. Masalah-masalah seperti hal di atas telah banyak mewarnai pemberitaan di media massa baik media cetak maupun elektronik.

Kasus kekerasan yang dilakukan oleh senior kepada junior di tingkat perguruan tinggi dan bahkan sampai merambah ke tingkat sekolah dasar yang sampai memakan korban jiwa. Kasus yang baru-baru ini terjadi terkait masalah radikalisme dalam pendidikan adalah kasus tawuran antar pelajar tingkat SMA. Kasus penganiayaan oleh guru kepada siswa, praktek bullying sering terjadi, penganiayaan antar pelajar, sampai kepada kasus pembunuhan antar siswa. Sangat miris memang, kasus-kasus seperti ini terjadi dalam dunia pendidikan.

Padahal seharusnya dunia pendidikan harus bersih dari hal-hal seperti itu. Kalau sudah terjadi maka muncul pertanyaan siapa yang disalahkan? Apakah guru? Siswa? Kurikulum? Atau materi pembelajaran?. Semua memiliki andil yang besar dalam mengantisipasi hal tersebut.

Salah satu cara yang ditawarkan agar terhindar dan membendung radikalisme dalam dunia pendidikan berawal dari kelas. Ruangan kelas yang nyaman, menyenangkan secara emosional akan mengakibatkan peserta didik senang dan bersikap simpati. Peserta didik difasilitasi untuk dapat mengoptimalkan potensi yang dimiliki dengan berbagai kegiatan yang merangsang dan menumbuhkan kemampuannya. Pendekatan yang bisa dilakukan oleh para guru di kelas adalah brain based approach.

\section{B. Pembahasan}

Radikalisme adalah paham atau aliran radikal. Radikal merupakan perubahan secara mendasar dan prinsip, atau dapat diartikan bahwa radikalisme berarti suatu konsep atau semangat yang berupaya mengadakan perubahan secara menyeluruh dan mendasar tanpa memperhitungkan adanya peraturan-peraturan atau ketentuan-ketentuan konstitusional, politis dan social yang 
berlaku. Dengan demikian, radikalisme berhubungan dengan cita-cita yang diperjuangakan, dan melihat persoalan sampai ke akar- akarnya.

Radikalisme bisa dibedakan ke dalam dua level, yaitu level pemikiran dan level tindakan. Pada level pemikiran, radikalisme masih berupa wacana, konsep dan gagasan yang masih diperbincangkan, yang intinya mendukung penggunaan caracara kekerasan untuk mencapai tujuan. Adapun pada level aksi atau tindakan, radikalisme bisa berada pada ranah social-politik dan agama $^{3}$

Bentuk radikalisme dalam institusi pendidikan di Indonesia harus mampu menjadi motor penggerak perubahan karakter dan budaya peserta didiknya dari karekter kekerasan dan budaya menghukum menjadi karakter yang merangsang kemajuan dan budaya santun. Institusi pendidikan mulai dari SD, SMP, SMA dan pendidikan tinggi harus mampu menstranfer dan mentransformasikan nilai-nilai dan budaya luhur kepada peserta didiknya.

Hal ini disebabkan karena setiap peserta didik merupakan generasi penerus bangsa yang nantinya akan menduduki posisiposisi penting baik di pemerintahan dan swasta. Banyak contoh kasus yang terjadi dimana kekerasan di lembaga pendidikan seperti: kekerasan di Sekolah Tinggi Pelayaran (STP) di Jakarta, kasus kekerasan yang berujung kematian di IPDN, kasus-kasus kekerasan yang diakibatkan oleh pelaksanaan Masa Orientasi Sekolah (MOS), Ospek dan lainnya. Beberapa saat yang lalu kekerasan antar pelajar SD di Kota Bukittinggi yang menganiaya teman sekelasnya dalam pelaksanaan pembelajaran yang di dokumentasikan melalui video dan dimasukkan dalam youtube dan bisa disaksikan oleh khalayak ramai.

Dunia pendidikan Indonesia mungkin salah satu dunia yang penuh dengan kekerasan dan budaya menghukum, tidak jarang didengar, dibaca dimedia dan bahkan ditonton di televisi di mana siswa sekolah ada yang dipukul, ditampar dan bentuk

${ }^{3}$ Abdul Munip, "Menangkal Radikalisme Agama di Sekolah”, dalam Jurnal Pendidikan Islam, Volume 1, Nomor 2, (Desember 2012), h. 162. 
kekerasan lainnya. Hal ini merupakan salah satu citra buruk yang ditunjukkan oleh para pendidik kepada peserta didiknya.

Kepatuhan dan ketaatan pada suatu aturan tidak sematamata disandarkan pada perbuatan-perbuatan menghukum dan memberikan kejutan-kejutan kekerasan, tetapijuga dapat dilakukan dengan upaya-upaya yang santun dan berbudaya. Walaupun tidak semua pendidik melakukan tindakan kekerasan dan menetapkan budaya menghukum kepada peserta didiknya tetapi apa yang muncul kepermukaan menjadi suatu preseden buruk bagi kemajuan dan perkembangan dunia pendidikan di Indonesia.

Insitusi pendidikan pada dasarnya merupakan tempat untuk memanusiakan manusia. Artinya bahwa ada upaya-upaya nyata, sadar dan sistematis yang dilakukan secara terus menerus untuk merubah pola pikir dan pola sikap seseorang yang sebelumnya tidak baik bahkan jahat menjadi baik, lebih baik dan sangat baik. Konsep dasar pendidikan inilah yang seharusnya menjadi acuan dan pedoman nyata bagi para pendidikan dalam rangka memanusiakan manusia.

Kekerasan demi kekerasan apabila terus berlanjut maka akan mematikan kreativitas dan semangat belajar peserta didik. Institusi pendidikan yang diharapkan dapat menjadi media bagi pengembangan potensi berubah menjadi transfer dan transformasi budaya kekerasan dan budaya menghukum yang sangat bertentangan dengan nilai-nilai dan konsep dasar pendidikan.

Radikalisme dalam dunia pendidikan justru tumbuh dilembaga pendidikan negeri. Sebagai contohnya Media tempo menyebutkan bahwa terdapat $13 \%$ siswa mendukung terhadap gerakan radikalisme, $14 \%$ siswa setuju dengan cara Imam Samodra di dalam melakukan terorisme. Selain itu Majalah Tempo juga menyebutkan bahwa terdapatmayoritas siswa bersedia memberikan dukungan dan kesediaan terlibat untuk merusak tempat hiburan, merusak anggota aliran yang menyimpang, merusak tempat ibadah agama lain, dan membantu umat Islam di daerah konflik.

Gejala radikalisme dalam dunia pendidikan menjadi ancaman serius bagi kenyamanan generasi muda saat ini dan di masa yang akan datang. Hal yang tidak dapat dipungkiri akhirakhir ini bahwa radikalisme semakin menguat dan menyusut 
kepada pelaku sekaligus korbannya adalah kalangan generasi muda sebagai penerus bangsa dalam dunia pendidikan. Pelaku Bom, contohnya di Sarinah Thamrin Jakarta baru-baru ini adalah generasi muda, tragedi bom Marriot, kalten dan Solo pelakunya beberapa di antaranya masih aktif sebagai siswa di sekolah tertentu.

Hal ini menjadi salah satu bukti bahwa sekolah menjadi ruang terbuka bagi penyebaran dan penanaman paham apa saja, termasuk paham-paham tertentu yang mengarah kepada radikal. Namun sayangnya pihak sekolah banyak yang tidak peduli dengan paham-paham radikal yang diajarkan melalui berbagai kegiatankegiatan ekstrakurikuler di sekolah. Kegiatan semacam ini menjadi wahana masuk yang sangat baik untuk menggait kelompok siswa di sekolahan.

Guna mengantisipasi masuknya radikalisme dalam pendidikan, Kementrian Pendidikan Nasional menekankan kurikulum yang berbentuk nilai-nilai nasionalisme dan kebangsaan pada peserta didik. Perubahan itu dilakukan tidak hanya dijenjang pendidikan tinggi, namun juga dijenjang sekolah mulai dari pendidikan dasar hingga menengah.Gencarnya gerakan radikalisme yang menyusup di lembaga-lembaga pendidikan membuat dunia pendidikan nasional menjadi perhatian di Masyarakat. Kritikan datang dari berbagai kalangan, tentang adakalanya kelemahan pada system kurikulum pendidikan yang ada.

Menteri pendidikan Nasional yang lalu M. Nuh menyebutkan bahwa guna meredam radikalisme yang terjadi dikalangan pelajar maka seluruh pihak terkait dihimbau untuk lebih gencar mengedepankan pendidikan karekter kepada para peserta didik. Menurut Nuh, untuk mencengah segala tindakan radikalisme adalah dengan menanamkan rasa cinta tanah air dan rasa empati sesame kepada para peserta didik sehingga tidak ada lagi pemikiran untuk melakukan radikalisme.

Selain itu Nuh juga menjelaskan dalam pendidikan karkter ada tiga hal utama yang harus ditanamkan yaitu kesadaran sebagai makhluk Tuhan YME, keilmuan dan kecintaan, serta kebanggaan terhadap tanah air. Terkait dengan banyaknya gejala radikalisme yang lahir dan tumbuh di lingkungan sekolah. Bukan hanya di 
sekolah saja ditempat lain juga banyak maka perlu ada kerjasama dengan pihak-pihak terkait untuk mengatasi hal tersebut.

Fenomena meningkatnya tindakan redikalisme dikerenakan dangkalnya pemahaman terhadapagama.Karenaitu, upaya preventif yang tepat saat ini adalah dengan merevitalisasi pendidikan agama dan akhlak di sekolah, keluarga, maupun masyarakat. Pendidikan dan pelajaran agama yang dijalankan saat ini hanya bersifat formalitas, materi dan tidak mendorong pembentukan moral dan karakter siswa. Selain itu alokasi jam pelajaran agama dan akhlak ditingkatkan dari sisi kuantitas dan kualitasnya. Selain itu materi pelajaran non agama atau umum seharusnya juga diarahkan pada penguatan akhlak dan karekter siswa sehingga tidak terlepas dari esensi pendidikan sebagaimana diamanahkan oleh UUD 1945 dan UU No. 20 Tahun 2003 tentang system pendidikan nasional.

Soedijarto berpendapat bahwa pendidikan memiliki kedudukan sebagai tiang dan pengawal suatu masyarakat, Negara dan memahami strategisnya system pendidikan nsional ${ }^{4}$. Namun pada pelaksanaannya penyelenggaraan system pendidikan nasional mengabaikan kedudukan strategis pendidikan nasional dan bahkan kurang memberikan perhatian yang memadai terhadap pendidikan nasional sebagai wahana pembentukan karekater bangsa.

Selain itu proses pembentukan pengetahuan adalah upaya membantu siswa untuk memahami, mencari tahu dan menentukan bagaimana suatu pengetahuan atau teori pada dasarnya secara implisit tercipta karena adanya pengaruh budaya tertentu, kelompok dengan status social tertentu yang terjadi pada saat itu. Hal ini sudah menjadi tujuan dari pendidikan adalah pilar paling penting dalam membangun masyarakat berbudaya dan berperadaban.

Konsepsi pendidikan telah mengalami berbagai evolusi. Evolusi pertama berlangsung saat individu menyadari pendidikan sebagai instrument pengembangan kepribadian. Evolusi kedua berlangsung saat manusia merasa tidak cukup hanya dengan kemampuan individual. Evolusi ketiga adalah saat pendidikan dapat menekan kesenjangan antara bangsa kaya dan miskin. Pendidikan

${ }^{4}$ Soedijarto, Landasan dan Arah Pendidikan Nasional Kita (Jakarta Kompas, 2008), h. 325. 
dalam evolusi ini digunakan untuk kesetaraan bersama diantara bangsa-bangsa di dunia termasuk Indonesia.

Pengembangan pendidikan yang berorientasi pada penegakan moralitas dapat dilakukan dengan mengembangkan: nilai-nilai demokratis, pengembangan kehidupan kewargaan dan nilai-nilai komunitas, pengembangan pemerintahan yang bersih, pembentukan identitas nasional, pengembangan ikatan sosiaal dan kebinekaan di antaranya toleransi, keadilan social dan pengembangan kehidupan pribadi serta pengembangan nilainilai keluarga ${ }^{5}$.

Pendidikan yang membentuk kepribadian dan karakter berawal dari penegakkan etika dan moral dalam diri, keluarga, sekolah dan masyarakat. Dalam pilar yang dikemukakan oleh UNESCO dimulai dari belajar untuk mengetahui, belajar untuk melakukan, belajar untuk menjadi sesuatu dan belajar untuk hidup bersama. Apa yang telah dicanangkan UNESCO tersebut sebenarnya mendorong untuk menjadikan warga belajar untuk dapat hidup berdampingan dengan orang lain dengan damai di kehidupannya.

None of aforementioned functions of attributes of the human being, including faith, can be fully developed, unfolded or unlocked withouth exposure to education ${ }^{6}$. Tidak akan dapat terjadi pengembangan kepribadian dan karakter peserta didik tanpa adanya pendidikan yang berarti untuk kepentingan kehidupan mereka untuk masa sekarang dan akan datang.

Realitas pada proses pembelajaran menunjukkan bahwa proses pembelajaran lebih banyak mengacu pada target pencapaian kurikulum dibandingkan dengan menciptakan peserta didik yang cerdas secara utuh. Akibatnya, peserta didik diberikan berbagai macam informasi tanpa diberi kesempatan untuk melakukan telaahan dan perenungan secara kritis, sehingga peserta didik tidak mampu memberikan respons yang positif. Mereka dianggap seperti kertas kosong yang siap menerima coretan informasi dan

${ }^{5}$ Suyanto, Dinamika Pendidikan Nasional (Jakarta: PSAP Muhammadiyah, 2006), h, 145.

${ }^{6}$ Ferdinand J. Potgieter and Johannes L. Van der walt, "Is religious fundamentalism our default sprituallity: implications for teacher education," HTS teolegies studies/ theological studies 70(1). http://dx.doi.org/10.4102/hts. U70i1. 2082. h. 5 
ilmu pengetahuan. Padahal sebaliknya mereka sudah membawa pengetahuan dasar yang telah dimilikinya melalui membangun pengetahuan dan pengalaman.

Kegiatan yang terjadi di dalam ruang belajar masih menempatkan peserta didik sebagai objek pembelajaran dengan aktivitas utamanya untuk menerima dan menghafal materi pelajaran. Selanjutnya mengerjakan tugas dengan penuh keterpaksaan, menerima hukuman atas kesalahan yang diperbuat. Jarang sekali guru memberikan penghargaan dan pujian atas jerihpayah mereka.

Oleh karena itu, dalam upaya mengubah pembelajaran sehingga dapat memberdayakan otak secara optimal maka perlu diciptakan pembelajaran dengan orientasi pada upaya pemberdayaan otak peserta didik. Strategi yang terkait dengan cara mengimplementasikan brain based teaching yaitu : menciptakan suasana atau lingkungan yang mampu merangsang kemampuan berpikir peserta didik, menghadirkan peserta didik dalam lingkungan pembelajaran yang menyenangkan dan membuat suasana pembelajaran yang aktif dan bermakna.

Brain based learning strategy! What is all about? To many, the term "brain-based" learning sounds redundant. It n't all teaching and learning brain based. Advocates of brain based teaching insist that that there is a difference between "brain compatible" education and "brain antagonistic" teaching practices and methods, which can actually impair learning ${ }^{7}$

Pertama menciptakan suasana atau lingkungan yang mampu merangsang kemampuan berfikir peserta didik. Strategi ini bisa dilakukan terutama pada saat guru memberikan soal-soal untuk mengevaluasi materi pelajaran. Soal-soal yang diberikan harus dikemas seatraktif mungkin sehingga kemampuan berpikir peserta didik lebih optimal, seperti melalui teka-teki, simulasi, permainan dan sebagainya.

Kedua menghadirkan peserta didik dalam lingkungan pembelajaran yang cukup menyenangkan. Guru tidak hanya memanfaatkan ruangan kelas untuk membelajarkan peserta didik,

7 Samuel adejare Awolala, "Effect of brain based learning strategy on student's achievement in senior secondary school mathematics in oyo state, Nigeria”, dalam Cypriot Journal of educational Sciences . Vol. 2, (Th. 2011), h. 94. 
tetapi juga tempat-tempat lainnya, seperti di taman, di lapangan bahkan di luar sekolah. guru harus menghindarkan situasi pembelajaran yang dapat membuat peserta didik merasa tidak nyaman, mudah bosan atau tidak senang terlibat di dalamnya. Strategi pembelajaran yang digunakan lebih menekankan pada diskusi kelompok yang diselingi permainan menarik serta variasi lain yang kiranya dapat menciptakan suasana yang menggairahkan peserta didik dalam belajar.

Hal ini dijelaskan oleh Jensen bahwa harapan meningkatkan kimia otak dapat dilakukan dengan meningkatkan suasana hati dan ketekunan sehingga meningkatkan hasil belajar. ${ }^{8}$ Mengelola dan mengkondisikan kelas yang kondusif adalah hal yang sangat mutlak yang harus dilakukan oleh guru di dalam proses pembelajarannya. Hal ini disebabkan karena otak akan bekerja optimal dalam suasana yang enjoy dan menyenangkan. Potensi yang ada dalam diri peserta didik akan dapat berkembang sesuai dengan kemampuan yang dimiliki oleh setiap peserta didik.

Ketiga membuat suasana pembelajaran yang aktif dan bermakna bagi peserta didik. Pembelajaran yang aktifdan bermakna hanya dapat dilakukan apabila peserta didik secara fisik maupun psikis dapat beraktivitas secara optimal. Strategi pembelajaran yang digunakan dikemas sedemikian rupa sehingga mahasiswa terlibat secara aktraktif dan interaktif, melalui model pembelajaran yang bersifat demonstrasi.

Apa yang dikemukakan tersebut merupakan upaya konkrit dalam meningkatkan kualitas pembelajaran. Namun kunci keberhasilan itu semua terletak pada kemauan dan kemampuan guru untuk mereformasi cara dan strategi pembelajarannya serta berani untuk menggeser paradigma berfikirnya, sehingga lebih bersifat praktis ketimbang teoritis.

Untuk mewujudkan hal itu diperlukan suatu pendekatan brain based teaching yang menawarkan metode sederhana dan metode yang relatif mudah untuk memahami dan menjelaskan cara-cara yang disukai orang untuk belajar dan berkembang. Pembelajaran yang digunakan mempertimbangkan struktur pembelajaran dengan menggabungkan pembelajaran emosional,

${ }^{8}$ Eric Jensen, Super Teaching (California: A SAGE Company, 2009), h. 114. 
sosial, kognitif, fisik dan reflektif. Dengan demikian akhirnya peserta didik memiliki hasrat untuk belajar, mempunyai visi untuk melihat apa yang mungkin, punya niat untuk mengembangkan pengetahuan dan kecakapan. Selain itu peserta didik mampu melakukan tindakan untuk mengubah mimpi menjadi kenyataan, selanjutnya peserta didik akan memiliki refleksi untuk memantau diri dan teguh pada pendirian.

Pendidikan toleran dan inklusif harus dibangun di atas karakter anak didik yang mengedepankan kerendahan hati, kemurahan hati, keramahan, dan kesopanan dalam menghargai orang lain'. Dengan Brain based learning dapat mengatasi kondisi umum peserta didik dalam belajar diantaranya takut, gelisah, bosan, apatis, frustasi dan bingung. Kondisi-kondisi ini akan sangat berpengaruh kepada proses pembelajaran yang terjadi sehingga berdampak pada hasil yang diperoleh. Keadaan ini dapat beransur-ansur berubah menjadi kondisi peserta didik yang paling diharapkan yaitu memiliki perasaan antisipasi, menyakinkan diri, besemangat, ingin tahu, gembira dan cerah.

Keadaan peserta didik yang diharapkan tersebut akan mampu menjadikan pembelajaran mencapai tujuan yang ingin dicapai sebelumnya. Untuk mencapai keadaan seperti itu maka peran guru akan sangat berpengaruh dalam mengkondisikan kelas. Hal ini disebabkan karena dalam pembelajaran di kelas guru adalah sebagai ujung tombak pembelajaran, mau berhasil atau tidaknya pembelajaran di kelas sangat tergantung kepada bagaimana guru bisa memfasilitasi peserta didiknya dalam belajar. Semakin inovatif dan kreatif guru dalam memfasilitasi pembelajaran di kelas, maka akan berdampak pada keberhasilan peserta didik dalam belajar.

Jika pembelajaran di kelas sudah mengindahkan suasana yang menyenangkan maka peserta didik akan jauh dari perasaan bosan dan fikiran serta prilaku yang negative lainnya. Dengan demikian akan mengakibatkan peserta didik yang memiliki jiwa dan perasaan yang halus sehingga sikap kekerasan dan antisipatif akan dapat terhindarkan dari setiap diri peserta didik. Untuk mewujudkan hal ini peran guru dalam menerapkan brain

${ }^{9}$ Irwan Masduqi, "Deradikalisasi Pendidikan Islam Berbasis Khazanah Pesantren”, dalam Jurnal Pendidikan Islam, Vol. II, Nomor 1, Juni 2013. 
based learning dalam proses pembelajaran di kelas akan sangat besar pengaruhnya.

Penelitian yang dilakukan oleh Erkan, dkk menjelaskan bahwa to interpret this as an indication of the likelihood that the brain based learning approach will be related to higher attitude anda motivation. Requires adherence to line of not unreasonable assumptions, but they are assumptions ${ }^{10}$

Dari uraian tersebut dijelaskan bahwa ada hubungan yang signifikan antara pendekatan brain based learning yang digunakan dengan sikap dan motivasi peserta didik dalam pembelajaran. Hal ini akan berdampak pada semangat dan keinginan peserta didik untuk selalu meningkatkan diri dan menjauhkan sikap-sikap yang negate untuk mencapai tujuan hidupnya.

Pembelajaran brain based teaching berusaha mengoptimalkan cara kerja otak dalam menangkap informasi yang berasal dari luar diri. Pendekatan ini mengaharuskan guru mampu memfasilitasi peserta didik dengan memaksimalkan teater otak. Teater itu terdiri dari pembelajaran emosional, sosial, kognitif, fisik dan refleksi. Pembelajaran dengan pendekatan ini sangat menekankan peran emosi dalam pembelajaran. Emosi akan menginformasikan tentang pemikiran peserta didik. Pembelajaran yang menyeluruh sebaiknya menghargai emosi, perasaan, keyakinan, kebutuhan, masalah, sikap dan keterampilan yang dimiliki peserta didik serta melibatkan semua hal dalam proses pembelajaran.

Untuk mendukung kenyamanan jangka panjang dengan profesi guru harus ingat bahwa peserta didik senang bekerja dengan guru yang bisa dipercaya, adil dan peduli. Peserta didik menginginkan guru menguasai pelajaran yang diajarkan dan mereka berharap guru peduli kepada mereka ${ }^{11}$. Dalam hal ini harapan peserta didik tidak hanya memiliki seorang guru yang cerdas secara pengetahuan namun yang diinginkan peserta didik adalah guru yang benar-benar peduli dan memahami mereka secara pribadi. Dengan demikian guru dituntut untuk dapat mengayomi peserta didiknya tanpa perbedaan diantara mereka.

${ }^{10}$ Erkan Akyurek and Ozlem Afacan, "Effects of Brain Based Learning Approach on Students' motivations and attitude levels in science class", dalam Mevlana International Journal of Educations (MIJE), Vol. 3 (1), April 2013.

${ }^{11}$ Barbara K Given, Brain Based Teaching (Aleksandria: TP, 2002), h. 337. 
Jika di lembaga pendidikan, guru mengembangkan pendekatan brain based learning seperti ini, maka akan dapat dipredikasi semua peserta didik akan belajar dengan senang, memiliki sikap yang positif, motivasi yang tinggi serta kegiatan pembelajaran sesuai dengan system kerja otak siswa. Hal ini akan dapat membendung budaya radikalisme yang berlebihan dalam dunia pendidikan.

Proses pembelajaran formal maupun non formal hendaknya memperhatikan perkembangan prilaku manusia, semakin hari semakin kompleks sehingga mental spiritual hendaknya selalu menyertai ${ }^{12}$. Hal ini menjadi pertimbangan bahwa jika hal ini tidak diindahkan maka akan terjadi kejahatan yang akan dilakukan oleh orang-orang pandai tetapi tidakmemiliki moralyangbaik. Kejahatan yang dilakukan oleh orang pandai dan cerdik dikalangan sekolahan sampai perguruan tinggi berakibat lebih buruk jika dibandingkan dengan kejahatan yang dilakukan oleh orang bodoh.

Dunia akan mengalami krisis ketika kecerdasan intelektual (IQ) mengalami kenaikan yang diikuti dengan penurunan kecerdasan emosional (EQ). orang akan menjadi pintar tetapi sadis. Untuk itu perlu ada keseimbangan keduanya, pintar tetapi mampu bermanfaat dan diterima sebagai individu yang memiliki kematangan emosional.

Sekolah, ruang kelas dan para guru dapat menciptakan lingkungan yang rumit dan sibuk akan dapat memicu tanggapan yang kompleks. Beberapa gejala frustasi belajar bisa terjadi hanya dalam kondisi spesifik. Hal semacam ini menuntut pencengahan dengan segera, ada yang mungkin menuntut layanan psikologis atau layanan lainnya, ada yang mungkin menuntut pendekatan pembelajaran yang spesifik yang sesuai dengan kebutuhan.

Peserta didik akan selalu menyadari bahwa kehidupan social dan interaksi yang baik akan dapat menyebabkan pengetahuan dan pengalaman yang baik untuk kehidupan yang lebih baik dimasa sekarang dan yang akan datang. Peserta didikakan dapat memahami pentingnya orang lain dalam kehidupan dan keberhasilan mereka disaat yang akan datang.

${ }^{12}$ Agus Irianto, Pendidikan sebagai investasi dalam pembangunan suatu bangsa (Jakarta: Kencana, 2013), h. 64. 
Peserta didik akan dapat menciptakan kondisi yang selalu damai dan menyenangkan. Menjauhkan kekerasan dan kerusakan karena pada prinsipnya mereka telah diajarkan bagaimana melakukan kegiatan yang positif dan diajarkan berbagai keterampilan hidup yang berguna bagi kehidupan pribadi dan orang lain di lingkungannya.

Proses pembelajaran harus dapat mendorong dilakukannya kegiatan pembelajaran untuk mengetahui dan menemukan sesuatu, belajar melakukan dan mengerjakan, belajar untuk mandiri dan belajar untuk bisa hidup bersama dengan orang lain. Jika hal ini dapat diterapkan di dalam ruang pembelajarn maka tidak aka nada kasus-kasus yang mengarah kepada radikalisme.

Beberapa cara yang dapat dilakukan dalam upaya membendung radikalisme dalam dunia pendidikan adalah:pertama kurikulum pendidikan harus memberi peluang bagi perkembangan semua aspek perkembangan peserta didik baik fisik, emosi, social dan konkrit melalui multi pendekatan yang interaktif. Kedua proses belajar harus dipandang sebagai proses interaktif dimana guru memfasiliasi suatu lingkungan belajar yang memungkinkan anak belajar interaksi aktif baik dengan guru, teman sebaya atau media pembelajaran serta anak menggali dan menemukan sendiri pemahaman akan konsep yang dipelajari.

Ketiga kegiatan pembelajaran serta media pembelajaran yang digunakan harus konkrit, nyata dan beragam serta relevan dengan kehidupan peserta didik. Keempat guru harus memberikan empiris belajar yang variatif, memberikan tantangan, dan meningkatkan kemampuan anak. Kelima perencanaan pembelajaran harus didasarkan hasil pengamatan dan tingkat perkembangan peserta didik.

Untuk mewujudkan hal tersebut maka perlu cara untuk dapat merangsang fikiran peserta didik dengan hal sebagai berikut: pertama peserta didik harus belajar bagaimana belajar dan belajar bagaimana berfikir. Kedua belajar harus menyenangkan disamping membangun percaya diri. Ketiga pengetahuan harus disampaikan dengan pendekatan multi sensori dan multi model dengan menggunakan berbagai bentuk kecerdasan. Keempat orang tua khususnya dan masyarakat umumnya harus terlibat sepenuhnya 
dalam pendidikan anak-anaknya. Kelima sekolah harus menjadi persiapan sebenar-benarnya bagi dunia yang nyata. Keenam prinsipprinsip manajemen harus dapat mengilhami dunia persekolahan.

Dengan demikian maka seorang guru dapat merangsang penggunaan berbagai kecerdasan pada peserta didiknya. Hal ini dapat dilakukan dengan berbagai macam cara diantaranya adalah menciptakan suasana belajar yang menyenangkan, demokratis dan antusias. Selain itu peran orang tua dan masyarakat juga akan sangat menentukan dalam keberhasilan pendekatan ini.

Pembaharuan pendekatan salah satu yang harus dilakukan untuk meingkatkan mutu pendidikan. Indikator keberhasilan pembaharuan pendekatan adalah adanya perubahan pola kegiatan pembelajaran sehari-hari. Adapun perubahan-perubahan yang diinginkanmencakupberbagaiaspekmulaidariperencanaansampai pada pendekatan yang digunakan. Diharapkan reorentasi tersebut dapat mempengaruhi guru dalam melaksanakan pembelajaran, pemilihan media dan pola evaluasi dalam menentukan hasil kualitas pembelajaran. Salah satunya adalah dengan pendekatan.

Pendekatan Brain based learning adalah pembelajaran yang dirancang untuk disesuaikan dengan cara kerja otak secara alamiah untuk belajar. Adapun konsep dasarnya adalah sebagai berikut: mensinergikan cara kerja otak, belahan otak kanan, belahan otak kiri, gaya belajar, multiple intelligence, remembering (how to memorize), emotional brain, reducing stress dan pengharapan dosen (teacher expectations). Hal serupa di jelaskan oleh Gagne bahwa a particular situation may motivate one individual because of prior learning, experience, or expectations. ${ }^{13}$

Untuk itu dewasa ini guru dituntut memiliki keterampilan atau metode yang beragam agar proses pembelajaran tersebut menyenangkan dan mampu mengembangkan kemampuan peserta didik. Metode merupakan hal yang lebih penting dari materi yang akan diajarkan. Metode adalah cara yang paling tepat dan cepat, kata "cepat dan tepat disini sering diungkapkan dengan ungkapan efektif dan efisien. Di sini seorang guru harus memilih cara yang

${ }^{13}$ Robert M. Gagne, Walter W. Wager, etc, Prinsiples of instructional design, fifth edition (Wadworth: Thomson, 2005), h. 114. 
efektif dan efisien dalam mentransformasi dan mengembangkan pengetahuan peserta didiknya.

Pembelajaran yang efektif artinya adalah pembelajaran yang dapat dipahami murid secara sempurna, dalam hal ini ialah pembelajaran yang berfungsi pada peserta didik. "Berfungsi" artinya menjadi milik peserta didik, pembelajaran itu membentuk dan mempengaruhi pribadinya. Adapun pembelajaran cepat adalah pembelajaran yang tidak memerlukan waktu yang lama, artinya pembelajaran tersebut difasilitasi alat-alat pembelajaran yang dapat mempermudah pemahaman peserta didik terhadap materi yang diajarkan.

Agar metodeyang digunakan terasa nyaman, menyenangkan di dalam proses pembelajaran dan membuat para murid selalu bersemangat untuk mengikuti proses pembelajaran, seorang guru haruslah memiliki dasar-dasar pertimbangan sebelum menggunakan suatu metode. Selain metode, media juga harus menjadi bahan pertimbangan dalam proses pembelajaran.

Media pembelajaran merupakan salah satu komponen pendidikan yang mempunyai peranan penting dalam Kegiatan pembelajaran. Pemanfaatan media seharusnya merupakan bagian yang harus mendapat perhatian guru / fasilitator dalam setiap kegiatan pembelajaran. Oleh karena itu guru / fasilitator perlu mempelajari bagaimana menetapkan media pembelajaran agar dapat mengefektifkan pencapaian tujuan dalam proses pembelajaran.

Pada kenyataannya media masih sering terabaikan dengan berbagai alasan, antara lain: terbatasnya waktu untuk membuat persiapan mengajar, sulit mencari media yang tepat, tidak tersedianya biaya, dan lain-lain. Hal ini sebenarnya tidak perlu terjadi jika setiap guru / fasilitator telah mempunyai pengetahuan dan ketrampilan mengenai media.

Ward menjelaskan bahwa pembelajaran lebih merupakan proses yang menghasilkan perubahan kapasitas mental, keterampilan motorik, kesejahteraan emosi, motivasi, keterampilan sosial, sikap, dan struktur kognisi yang berkelanjutan. ${ }^{14}$ Selain itu

${ }^{14}$ Hellen Ward, Using Their Brains in Science (London: A SEGE Publication Company, 2007), h. 17. 
berhubungan dengan interaksi pembelajaran di kelas, maka terjadi hubungan antara peserta didik dan guru maka dijelaskan bahwa pembelajaran dipengaruhi oleh kepercayaan diri pembelajaran dan juga efektivitas guru dalam membuat keterhubungan. Aspek pembelajaran sosial dan emosional yang memberikan dampak pada kemungkinan materi pelajaran itu memiliki relevansi bagi peserta didik.

Pendekatan brain based learning merupakan pembelajaran yang menyelaraskan dengan cara otak yang didesain secara alamiah untuk belajar. Pendekatan ini sebuah pendekatan yang multidisipliner yang dibangun atas kebutuhan otak belajar. Pendekatan ini mempertimbangkan sifat alamiah otak dalam membuat keputusan. Dengan menggunakan apa yang diketahui, maka seseorang akan dapat menciptakan keputusan yang lebih baik.

Pertama Pembelajaran Emosional, Sistem pembelajaran emosional otak adalah sistem penuntut. Sistem ini harus nyaman sebelum pikiran bisa terlibat dalam pembelajaran kognitif. Namun, egoisme tidak boleh dibiarkan menguasai individu. Sistem pembelajaran emosional harus menjaga keseimbangan antara emosi dan egoisme. Ia juga harus menjaga keseimbangan dengan keempat sistem lain untuk memperoleh kenyamanan dan kesejahteraan diri secara menyeluruh.

Kedua pembelajaran sosial, Sistem pembelajaran sosial otak menginginkan afiliasi dan berharap untuk dihormati dan diakui oleh semua anggota kelompok. Sistem ini berjuang untuk memperoleh pujian dari orang lain yang dianggap penting dan menikmati pembelajaran sambil berhubugan dengan mereka yang memiliki pemikiran serupa. Kebutuhan untuk menjadi bagian dari kelompok merupakan kebutuhan terbesar sistem ini.

Ketiga Sistem pembelajaran kognitif adalah sistem pemprosesan informasi pada otak. Sistem ini menyerap masukan dari dunia luar dan semua sistem lain, menginterpretasikan masukan tersebut, serta memandu pemecahan masalah dan pengambilan keputusan. Tugas paling berat sistem kognitif adalah menilai sensasi emosional dan situasi sosial, kemudian mengambil tindakan berdasarkan penilaian tersebut. 
Keempat Sistem pembelajaran fisik otak melibatkan proses interaksi dengan lingkungan untuk mengembangkan pengetahuan dan kecakapan baru, atau untuk mengungkapkan beragam emosi atau konsep. Menggunakan sistem pembelajaran fisik untuk mempelajari informasi baru, memahami konsep yang sulit, dan mengembangkan kecakapan baru sama pentingnya dengan menunjukkan apa yang sudah dipelajari dengan meniru atau melalui ungkapan kreatif.

Kelima Pembelajaran reflektif merupakan sistem yang memantau dan mengatur aktivitas semua sistem otaklainnya.Sistem pembelajaran reflektif memiliki kebutuhan kuat untuk melakukan ujicoba dan ekslorasi dan dosen yang memandu eksplorasi itu membantu mahasiswa merenungkan emosi, interaksi, pemikiran, gagasan dan prilaku masa lalu, dan memikirkan kaitan semua itu dengan apa yang sedang terjadi saat ini.

Pendekatan brain based learning berorientasi pada pertimbangan pemenuhan kebutuhan siswa dalam pembelajaran. Jika kebutuhan peserta didik telah dapat terpenuhi maka tidak akan muncul masalah dalam pembelajaran. Sehingga dengan demikian peserta didik akan mampu menjadi pribadi yang andal dan jauh dari masalah-masalah yang telah diungkap sebelumnya. Peserta didik menjadi unggul dalam kecerdasan intelektuan, kecerdasan emosional dan kecerdasan spiritual.

Dengan cara seperti ini akan dapat membendung adanya kasus-kasus yang mengarah kepada radikalisme dalam dunia pendidikan. Masalah-masalah yang timbul berawal dari kehidupan pribadi yang sudah tidak nyaman akan mengakibatkan rasa frustasi dan akhirnya akan dilampiaskan dalam berbagai bentuk kegiatan yang merugikan pribadi dan orang lain di lingkungannya. Dengan demikian dengan memilih pendekatan yang tepat dalam dunia pendidikan akan dapat mencengah kasus-kasus seperti yang telah diulas sebelumnya.

\section{Kesimpulan}

Pendidikan yang dijalankan saat ini hanya bersifat formalitas, materi dan tidak mendorong pembentukkan moral dan karakter peserta didik. Padahal yang dibutuhkan peserta didik adalah pembelajaran yang mampu memberdayakan potensinya. 
Salah satu potensi yang sangat besar pengaruhnya dalam kehidupan peserta didik adalah brain (otak). Otak menyerap informasi dari lingkungan sekeliling, baik pada level sadar maupun tidak sadar.

Pendekatan brain based learning didasarkan pada cara otak belajar yang terbaik secara alamiah.Untuk itu kelas di sekolah harus dirancang sedemikian rupa sehingga dapat menstimulisasi otak dalam beraktivitas. Dengan penataan lingkungan terbaik untuk pembelajaran yang aman secara emosional. Hal ini akan dapat membendung sikap dan prilaku radikalisme dalam dunia pendidikan yang akhir-akhir ini marak terjadi di Indonesia. Penataan pendidikan melalui pendekatan brain based learning akan dapat meminimalisir dan membendung hal-hal yang bernuansa radikalisme dalam dunia pendidikan. []

\section{Daftar Pustaka}

Akyurek, Erkan and Afacan, Ozlem, "Effects of Brain Based Learning Approach on Students' motivations and attitude levels in science class", dalam Mevlana International Journal of Educations (MIJE), Vol. 3 (1), April 2013.

Awolala, Samuel adejare, "Effect of brain based learning strategy on student's achievement in senior secondary school mathematics in oyo state, Nigeria", dalam Cypriot Journal of educational Sciences, Vol. 2 , 2011.

Gagne, Robert M., Wager, Walter W., etc, Prinsiples of instructional design, fifth edition, Wadworrh: Thomson, 2005.

Given, Barbara K., Brain Based Teaching, Aleksandria: TP, 2002.

Irianto, Agus, Pendidikan sebagai Investasi dalam Pembangunan suatu Bangsa, Jakarta: Kencana, 2013

Jensen, Eric, Super Teaching, California: A SAGE Company, 2009.

Masduqi, Irwan, "Deradikalisasi Pendidikan Islam Berbasis Khazanah Pesantren", dalam Jurnal Pendidikan Islam, Vol. II, Nomor 1, Juni 2013.

Munip, Abdul, “Menangkal Radikalisme Agama di Sekolah”, dalam Jurnal Pendidikan Islam: Volume I, Nomor 2, Desember 2012. 
Potgieter, Ferdinand J. and walt, Johannes L. Van der, "Is religious fundamentalism our default sprituallity: implications for teacher education" dalam HTS teolegies studies/theological studies 70(1). http://dx.doi.org/10.4102/hts. U70i1.2082. 2014.

Soedijarto, Landasan dan arah Pendidikan Nasional Kita, Jakarta: Kompas, 2008.

Suyanto, Dinamika Pendidikan Nasional, Jakarta: PSAP Muhammadiyah, 2006.

Tilaar, Manifesto Pendidikan Nasional, Jakarta: Kompas, 2005.

Ward, Hellen, Using Their Brains in Science, London: A SAGE Publication Company, 2007. 